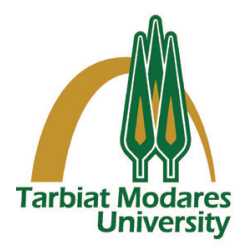

\title{
Screening and Investigation of Microbial and Chemical Properties of Meat Products in Hamadan Province, Iran during 2012-2015
}

\section{A R T I C L E I N F O}

Article Type

Original Research

\section{Authors}

Mehdi Ahmadi, $P h D^{1}$

Mahsa Alikord, $P h D^{1}$

Mohadeseh Pirhadi, $P h D^{1}$

Safdar Masoumi, $M S c^{2}$

Ebrahim Molaee Aghaee, $P h D^{1^{*}}$

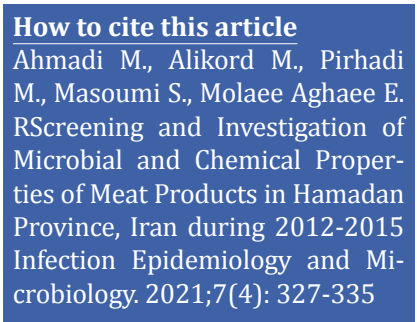

${ }^{1}$ Department of Environmental Health, Food Safety Division, School of Public Health, Tehran University of Medical Sciences, Tehran, Iran. ${ }^{2}$ Department of Epidemiology and Biostatistics, School of Public Health, Tehran University of Medical Sciences, Tehran, Iran.

\section{A B S T R A C T}

Background: This study aimed to investigate chemical and microbiological properties of 1260 meat product samples, including sausage, bologna, hotdog, Kebab, and hamburger, in Hamadan, Iran from 2012 to 2015.

Materials \& Methods: All microbial (total viable count as well as, Coliform, Salmonella, Escherichia coli, Staphylococcus aureus, Clostridium perfringens, mold, and yeast counts) and chemical (pH as well as salt, phosphate, sodium nitrite, moisture, protein, total fat, starch, nitrite, nitrate, and ash contents) properties were assessed by AOAC method.

Findings: Microbial tests on sausage and bologna samples showed that the total count of microorganisms was higher (37.3\%) than the national standard limit. In $11.3 \%$ of Kebab samples, the number of yeasts and molds was higher than the national standard limits. Also, in 3.5 and $17.07 \%$ of hamburger samples, the total count of microorganisms as well as the number of molds and yeasts were higher than the national standard limits, respectively. In $34.6 \%$ of bolognas, $15.9 \%$ of sausages, $3.8 \%$ of hamburgers, and $54.3 \%$ of hotdogs, the moisture content was above the national standard. The fat content was above the national standard in $34.7 \%$ of sausages, $1.4 \%$ of Kebabs, $9.8 \%$ of bolognas, $1.2 \%$ of hamburgers, and $6.5 \%$ of hotdogs.

Conclusion: The present study results showed that the level of contamination of a considerable number of samples was not matched with national standards, which could be a major health risk for consumers.

Keywords: Meat, Chemical, Microbial, Adulteration, Hamadan, Iran.

\section{CITATION LINKS}

[1] Nemati Niko Z, Jahed Khaniki G, Alikord M, MolaeeAghaee E. ELISA and copan... [2] Uradziński J, Weiner M. Food additives used in meat processing according to the... [3] World Health Organization. The state of... [4] Alikord M, Momtaz H, keramat J, Kadivar M, Rad AH. Species identification and... [5] Alikord M, Keramat J, Kadivar M, Momtaz H, Eshtiaghi MN, Homayouni-Rad A. Multiplex-PCR as a rapid... [6] Alikord M, Mohammadi A, Kamankesh M, .. [7] Bolinius DJ, Sobek A, Löf MF, Undeman E. Evaluating the... [8] Amit SK, Uddin MM, Rahman R, Islam SR, Khan MS. A review on... [9] Rehman NU, Hussain J, Ali L, Khan AL, Mabood F, Gillani SA, et al. Nutritional assessment... [10] Zerabruk K, Retta N, Muleta D, Tefera AT. Assessment of microbiological... [11] Miraglia D, Ranucci D, Trabalza-Marinucci M, Acuti G, Forte C, Codini M, et al. Microbiological... [12] Bintsis T. Microbial pollution... [13] Bhunia AK. Foodborne microbial... [14] Barbieri F, Montanari C, Gardini F, Tabanelli G. Biogenic... [15] Dehkordi MK, Shamsabadi MG, Banimehdi P. The occurrence of... [16] Association of Official Analytical Chemists. Official... [17] Regulation EC. No. 1151/2012 of the European Parliament... [18] Giatrakou V, Ntzimani A, Savvaidis I. Effect of... [19] Siripatrawan U, Noipha S. Active... [20] Petrou S, Tsiraki M, Giatrakou V, Savvaidis I. Chitosan dipping or... [21] Vasilatos G, Savvaidis I. Chitosan or rosemary... [22] Association of Official... [23] Association of Official Analytical Chemists. Official... [24] Borch E, Kant-Muermans M-L, Blixt Y. Bacterial... [25] Kotsanopoulos KV, Arvanitoyannis IS. The role of... [26] Syne S-M, Ramsubhag A, Adesiyun AA. Microbiological hazard analysis of... [27] Camino Feltes MM, Arisseto-Bragotto AP, Block JM. Food... [28] Kadariya J, Smith TC, Thapaliya D. Staphylococcus aureus and staphylococcal... [29] Rani Z, Hugo A, Hugo C, Vimiso P, Muchenje V. Effect... [30] Baek KH, Utama DT, Lee SG, An BK, Lee SK. Effects of... [31] Mann J, Truswell AS. Essentials... [32] Kong YW, Baqar S, Jerums G, Ekinci EI. Sodium and its role... [33] Parvizishad M, Dalvand A, Mahvi AH, Goodarzi F. A review of adverse effects and benefits of nitrate and nitrite... [34] Jalali M, Abedi D. Prevalence of... [35] Kamkar A. Determination of hydroxyproline as... [36] Shekarforoush S, Rokni N, Karim G, Razavi RS, Kiaie S, Abbasvali M. Study on the overview on food... [37] Sadeghi E, Hashemian A, Mohammadi M, Mohammadi R. Study on the microbiological... [38] Sulieman AM, Abdelhai M, Babiker ER. Some chemical and... [39] Menéndez RA, Rendueles E, Sanz JJ, Santos JA, García-Fernández MC. Physicochemical and microbiological characteristics of diverse Spanish cured meat...
Received: June 052021

Accepted: September 25,2021

Published: November 05,2021 


\section{Introduction}

Meat products are among the most commonly consumed items, which make up a large portion of the food daily consumed in different communities. One of the most challenging issues in the food industry is meat and its product safety ${ }^{[1]}$. Since processed meat products are made up of various ingredients, there is a possibility of fraud during the production of these products in related industries [2]. The utilization of low-quality ingredients has led to severe nutritional health problems and also food security concerns in recent years, especially in developing countries ${ }^{[3-}$ 6]. Strict observation and regulations must be applied and observed because of the high consumption rate, and it is necessary to evaluate the products thoughtfully during manufacturing [7]. The purpose of using food additives in the meat industry is to prevent food spoilage, create stability, preserve the nutritional value of products, adjust the $\mathrm{pH}$, and creat the desired flavor and color ${ }^{[8]}$. Therefore, chemical [9], microbial [10], physical, and sensory tests are performed to evaluate the quality of meat and its products [11]. Without proper health control, these products could be recognized as an important source of microbial contamination [12]. Salmonella, Yersinia enterocolitica, Campylobacter jejuni, Listeria monocytogenes, Escherichia coli, and anaerobic microbes such as Clostridium, are among the most prevalent contaminants identified in these food products [13]. Also, during the sausages production and maintenance process, biogenic amines are produced through decarboxylation of amino acids produced by microorganisms such as Bacillus, Enterobacteriaceae, Lactobacillus, Pediococcus, and Streptococcus ${ }^{[14]}$. The most common type of food poisoning is related to staphylococcal enterotoxins, causing resistance to antibiotics [15].
Therefore, these products must be manufactured based on strict domestic and international regulations.

Objectives: Due to the increasing consumption and importance of hygienic control of these products, this study aimed to investigate the microbial and chemical properties of meat products in Hamedan, Iran from 2015 to 2019 with a food safety approach.

\section{Materials and methods}

Chemical and microbiological analysis was carried out on 1260 samples of sausage, bologna, Kebab, hotdog, and hamburger in Hamadan province from 2012 to 2015. All microbial (total viable count as well as Coliform, Salmonella, E. coli, S. aureus, C. perfringens, mold, and yeast counts) and chemical $(\mathrm{pH}$ as well as salt, phosphate, sodium nitrite, moisture, protein, total fat, starch, nitrite, nitrate, and ash contents) properties were assessed by AOAC method $[16,17]$. Samples were collected and tested according to the guidelines of the Iranian Institute of Standards and Industrial Research. Data were analyzed by SPSS software Ver. 24.

Microbiological analysis: Samples (25 g) were mixed with $225 \mathrm{~mL}$ of sterile peptone water (0.1\%) (Merck, Darmstadt, Germany) and homogenized. Then $0.1 \mathrm{~mL}$ of serial dilutions of homogenized samples were cultured on agar plates. Total viable counts were assessed by plate count agar medium (PCA, Merck, Darmstadt, Germany) at $30^{\circ} \mathrm{C}$

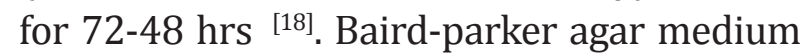
(BPA, Merck, Darmstadt, Germany) was used for $S$. aureus count for $48 \mathrm{hrs}$ at $37^{\circ} \mathrm{C}$. For mold and yeast count, $0.1 \mathrm{~mL}$ of suitable dilutions were pour-plated on Sabouraud dextrose agar medium (Merck, Darmstadt, Germany) at $25^{\circ} \mathrm{C}$ for 3-4 days ${ }^{[19]}$. Violet red bile glucose (VRBG) agar medium was utilized for Enterobacteriaceae by pour-overlay method 
for $48 \mathrm{hrsat} 37^{\circ} \mathrm{C}$ (Merck, Darmstadt, Germany) [20, 21]. Tryptose-sulfite-cycloserine (TSC) agar, egg yolk emulsion, egg yolk emulsion 50\%, chopped liver broth, thioglycollate medium, iron milk medium, lactose-gelatin medium, sporulation broth, motility-nitrate medium, buffered (M102), and Spray's fermentation medium (Merck, Darmstadt, Germany) were used for $C$. perfringens according to AOAC 976.30-1979 [22].

Chemical evaluations: For measurement of moisture content of meat products, lowfat samples were dried by microwave ovens for 3-5 min, then samples were placed between glass fiber pads, weighted, dried, and reweighted to determine moisture loss

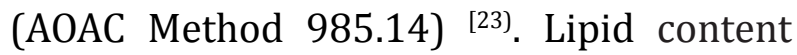
was assessed by AOAC method 991.36, which was done using Soxhlet extraction method with ether solvent, followed by gravimetric measurement. Solvent extraction with conventional organic solvents like ether was used to measure the total fat content as triglycerides. A modified solvent (chloroform-methanol) was used for phospholipids and other partial fats. Protein content was determined with Kjeldahl method, which involves a threestep approach to protein quantification, including digestion, distillation, and titration. In this method, the residual boric acid is then titrated using a standard acid, a suitable end-point indicator, and the numerical value of 6.25 as the conversion factor to estimate the total nitrogen content of the sample (AOAC, 976.05). Ash content was determined by AOAC method 920.153 (AOAC, 2016c); in this method, samples were placed in a muffle furnace (Fisher Scientific Isotemp Muffle Furnace, Ottawa, Ontario, Canada) at $525{ }^{\circ} \mathrm{C}$ for at least 16 hrs. To determine the $\mathrm{pH}$ value, $10 \mathrm{~g}$ of each sample was homogenized with $25 \mathrm{~mL}$ of neutral distilled water and filtered. The $\mathrm{pH}$ was determined using a $\mathrm{pH}$ meter (Digital,
Jenco 609). The nitrite and nitrate content in the samples was determined according to AOAC (1990). It is more effective than other colorimetric methods because it has a detection limit of $0.05 \mathrm{mg} / \mathrm{kg}$ for these substances in meat. The $\mathrm{NaCl}$ content of the samples was measured with a Fisher accumet selective ion analyzer, Model 750, fitted with an orion chloride electrode (model 94-17) and a double junction reference electrode. The salt content was determined according to procedures developed by Orion Research, Inc. (1980). Quimociac molybdophosphate gravimetric method was used to measure phosphorus pentoxide concentration in the raw emulsion.

Statistical evaluation: Data analysis was performed and represented as mean $\pm \mathrm{SD}$, and a $p$-value less than 0.05 was considered as significant. ANOVA test was applied in SPSS software (17:00). The normality of data was first evaluated by Kolmogorov-Smirnov test. Non-parametric tests were used for data analysis.

\section{Findings}

The results of microbial assessment are summarized in Table 1. According to the results of microbial tests on sausage and bologna samples, the total count of microorganisms in 174 cases (37.3\%), the number of Coliforms in six cases (1.3\%), and the count of $S$. aureus in eight cases $(1.7 \%)$ were more than the national standard of Iran. However, the counts of E. coli, Salmonella, C. perfringens, molds, and yeasts were acceptable according to the national standard. Also, in Kebab samples, S. aureus count in only one case and mold and yeast counts in ten cases $(11.3 \%)$ were above the national standard limits. The total count of microorganisms and the counts of E. coli, Salmonella, and Coliforms were below the national standard. In hamburger samples, the total count of microorganisms in seven 
Table 1) Frequency distribution of mean microbial properties in different meat product

\begin{tabular}{lcccccc}
\hline \multirow{2}{*}{ Parameters } & \multicolumn{2}{c}{ Sausage, bologna $\mathbf{N}=\mathbf{4 5 6}$} & \multicolumn{2}{c}{ Kebab $\mathbf{N}=\mathbf{8 8}$} & \multicolumn{2}{c}{ Hamburgers $\mathbf{N}=\mathbf{2 0 0}$} \\
\cline { 2 - 7 } & ${ }^{*} \mathrm{St}$ & $\mathrm{N}(\%)$ & ${ }^{*} \mathrm{St}$ & $\mathrm{N}(\%)$ & ${ }^{*}$ St & $\mathrm{N}(\%)$ \\
\hline Total count & $10^{5}$ & $174(37.3)$ & $10^{6}$ & 0 & $10^{6}$ & $7(3.5)$ \\
\hline Coliform & $<10$ & $6(1.3)$ & - & - & - & - \\
\hline E. coli & negative & 0 & - & - & - & - \\
\hline Salmonella & negative & 0 & negative & 0 & negative & 0 \\
\hline Staphylococcus & $<10$ & $8(1.7)$ & $10^{3}$ & $1(1.13)$ & $10^{3}$ & $1(0.5)$ \\
\hline Clostridium & $\leq 50$ & 0 & - & - & - & - \\
\hline Mold and yeast & $10^{2}$ & $1(0.02)$ & $10^{3}$ & $10(11.3)$ & $10^{3}$ & $35(17.07)$ \\
\hline
\end{tabular}

*St= National Standard limitation

cases (3.5\%), the number of molds and yeasts in 35 cases $(17.07 \%)$, and the count of $S$. aureus isolates in only one case were higher than the national standard. The counts of Salmonella, E. coli, and C. perfringens were lower than the national standard.

The frequency distribution of chemical properties higher than the national standard in different meat products, mean chemical factors, and the frequency distribution of mean chemical properties in different meat products in laboratory and factory samples are summarized in Tables 2, 3, and 4, respectively. There was no significant difference $(p>.05)$ between the samples tested in the laboratory in terms of chemical properties in different years $(p>.05)$. According to the results of chemical tests, in $34.6 \%$ of bolognas, $15.9 \%$ of sausages, $3.8 \%$ of hamburgers, and $54.3 \%$ of hotdogs, the moisture content was above the national standard. Also, in $30.7 \%$ of hamburgers, $34.7 \%$ of sausages, $5.9 \%$ of Kebabs, $15.6 \%$ of bolognas, and $15.2 \%$ of hotdogs, the amount of protein was below the national standard. The fat content of $34.7 \%$ of sausage samples, $1.4 \%$ of barbecues, $9.8 \%$ of bologna samples, $1.2 \%$ of hamburgers, and $6.5 \%$ of hotdogs was above the national standard. The $\mathrm{pH}$ value of all hamburger samples was based on the national standard of Iran. Also, the $\mathrm{pH}$ in $5.7 \%$ of bologna samples, $3.4 \%$ of sausages, and $4.3 \%$ of hotdogs was in line with the national standard. The ash content of sausages, barbecues, bolognas, hamburgers, and hotdogs was 20.8, 5.9, $15.6,30.7$, and $15.2 \%$ and higher than the national standard, respectively. The starch content of sausages, Kebabs, bolognas, hamburgers, and hotdogs was 24.3, 10.4, $13.8,57.6$, and $4.3 \%$, respectively, which were contradictory to the national standard. The salt content in all samples was also based on the national standard of Iran (Table 2). The average chemical properties of the products studied in the two sections of laboratory and company are presented in Table 3. There was a significant diference regarding the mean moisture content of barbecues and hotdogs between the laboratory and company samples ( $p=.001$ and $p=.002$, respectively), and the mean fat content of hotdogs in laboratory and factory samples was significantly different $(p=.002)$. There was a difference between the two types of samples in terms of the ash content $(p<.05)$. Only in hotdog samples, the mean starch content was significantly different between the laboratory and factory samples. In terms of the mean phosphate and nitrite content in bologna as well as the mean salt content in sausage and bologna, there were significant differents between 
Table 2) Frequency distribution of chemical properties higher than national standard in different meat products

\begin{tabular}{lcccccccccc}
\hline \multirow{2}{*}{ Parameters } & \multicolumn{2}{c}{ Sausage } & \multicolumn{2}{c}{ Kebab } & \multicolumn{2}{c}{ Bologna } & \multicolumn{2}{c}{ Hamburgers } & \multicolumn{2}{c}{ Hotdog } \\
\cline { 2 - 12 } & St & $\mathbf{N}(\%)$ & St & N (\%) & St & N (\%) & St & N (\%) & St & N (\%) \\
\hline Moisture & $\leq 63$ & $23(15.9)$ & $\leq 72.5$ & $0(0.0)$ & $\leq 63$ & $60(34.6)$ & $\leq 67.5$ & $3(3.8)$ & $\leq 63$ & $25(54.3)$ \\
\hline Protein & $\geq 13$ & $50(34.7)$ & $\geq 12$ & $4(5.9)$ & $\geq 13$ & $27(15.6)$ & $\geq 13.15$ & $24(30.7)$ & $\geq 13$ & $7(15.2)$ \\
\hline Fat & $\leq 18$ & $50(34.7)$ & $\leq 17.75$ & $1(1.4)$ & 17.75 & $17(9.8)$ & $\leq 18.4$ & $1(1.2)$ & $\leq 18$ & $3(6.5)$ \\
\hline Ash & $\leq 2.6$ & $30(20.8)$ & $\leq 3$ & $5(7.4)$ & 2.6 & $32(18.4)$ & $\leq 2.5$ & $21(26.9)$ & $\leq 2.6$ & $9(19.5)$ \\
\hline Starch & $\leq 6$ & $35(24.3)$ & $\leq 5.5$ & $7(10.4)$ & $\leq 6$ & $24(13.8)$ & $\leq 5.25$ & $45(57.6)$ & $\leq 6$ & $2(4.3)$ \\
\hline pH & $5.6-6.2$ & $5(3.4)$ & - & - & $5.6-6.2$ & $10(5.7)$ & - & $0(0.0)$ & $5.6-6.2$ & $2(4.3)$ \\
\hline Salt & $\geq 2$ & $0(0.0)$ & - & - & $\geq 2$ & $0(0.0)$ & - & $0(0.0)$ & - & - \\
\hline Phosphate & 0.57 & $3(2.8)$ & $\leq 5$ & $0(0.0)$ & 0.57 & $7(4.4)$ & - & - & - & - \\
\hline Nitrite & 86.6 & $2(1.3)$ & - & - & $\geq 86.6$ & $0(0.0)$ & - & - & - & - \\
\hline
\end{tabular}

Table 3) Mean of chemical factors in different products

\begin{tabular}{lccccc}
\hline \multirow{2}{*}{ Parameters } & Hamburgers & Kebab & Bologna & Sausage & Hotdog \\
\cline { 2 - 6 } & Mean \pm SD & Mean \pm SD & Mean \pm SD & Mean \pm SD & Mean \pm SD \\
\hline Moisture & $60.7 \pm 5.5$ & $64.2 \pm 3.4$ & $63.0 \pm 4.2$ & $59.3 \pm 4.3$ & $63.3 \pm 1.9$ \\
\hline Protein & $13.4 \pm 1.5$ & $14.0 \pm 2.5$ & $14.0 \pm 1.5$ & $13.0 \pm 1.8$ & $14.2 \pm 1.9$ \\
\hline Fat & $13.5 \pm 3.05$ & $13.9 \pm 2.4$ & $14.2 \pm 3.8$ & $17.6 \pm 4.5$ & $13.4 \pm 2.6$ \\
\hline Ash & $2.2 \pm 0.68$ & $1.9 \pm .60$ & $2.3 \pm 0.41$ & $2.6 \pm 0.85$ & $2.3 \pm 0.71$ \\
\hline Starch & $6.7 \pm 2.18$ & $4.7 \pm 0.10$ & $5.2 \pm 1.6$ & $6.3 \pm 1.5$ & $5.5 \pm 0.72$ \\
\hline pH & $5.9 \pm 0.30$ & $5.9 \pm 0.28$ & $6.0 \pm 0.20$ & $6.0 \pm 0.30$ & $6.0 \pm 0.21$ \\
\hline Salt & $1.0 \pm 0.0$ & $1.0 \pm 0.0$ & $1.0 \pm 0.11$ & $1.0 \pm 0.13$ & $1.0 \pm 0.00$ \\
\hline Phosphate & - & $0.40 \pm 0.0$ & $0.42 \pm 0.08$ & $0.4 \pm 0.07$ & $0.40 \pm 0.00$ \\
\hline Nitrite & - & - & $49.6 \pm 29.6$ & $68.9 \pm 30.4$ & $70.4 \pm 12.9$ \\
\hline
\end{tabular}

the two types of sample $(p<.001)$ (Table 4). Discussion

Meat products are one of the most common and widely consumed foods that make up a significant part of the food chain in different communities ${ }^{[24]}$. The safety and quality of the food industry is increasing in most parts of the world. The quality control of meat products and their adaptation to the national and international regulations set by the administrative organization in each country should be considered [25]. The results of quality parameters of manufactured products and their comparison with the standard limits make it possible to specify the quality of these products. The important issue about microbial contamination of meat products is that their origin could be attributed to staff, raw materials, factory environment and equipment, production, and packaging process ${ }^{[26]}$. Currently, despite technological advances in the food industry and related health control strategies, foodborne diseases remain one of the most important health challenges in the world ${ }^{[27]}$. S. aureus is one of the most important foodborne pathogenic bacterium causing various diseases in humans and animals. The main cause of staphylococcal food poisoning is the production of enterotoxins by bacteria in food sources such as meat products ${ }^{[28]}$. About $55 \%$ of the samples tested were infected with $S$. aureus, and the mean bacterial count was $8.3 \times 10^{2} \mathrm{cfu} / \mathrm{g}$. The number and type of 
Table 4) Frequency distribution of mean chemical properties from different meat products in laboratory and factory samples

\begin{tabular}{|c|c|c|c|c|c|c|c|c|c|c|c|}
\hline \multirow{2}{*}{ Parameters } & \multirow{2}{*}{ Source } & \multicolumn{2}{|c|}{ Sausage } & \multicolumn{2}{|c|}{ Kebab } & \multicolumn{2}{|c|}{ Bologna } & \multicolumn{2}{|c|}{ Hamburgers } & \multicolumn{2}{|c|}{ Hot dog } \\
\hline & & Mean \pm SD & p.v & Mean \pm SD & p. v & Mean \pm SD & p.v & Mean \pm SD & p.v & Mean \pm SD & p.v \\
\hline \multirow{2}{*}{ Moisture } & part & $57.8 \pm 3.7$ & \multirow{2}{*}{0.28} & $63.0 \pm 4.0$ & \multirow{2}{*}{0.01} & $63.3 \pm 5.9$ & \multirow{2}{*}{0.98} & $61.0 \pm 4.6$ & \multirow{2}{*}{0.75} & $66.2 \pm 0.3$ & \multirow{2}{*}{0.002} \\
\hline & morv & $59.4 \pm 4.3$ & & $64.8 \pm 2.7$ & & $63.0 \pm 4.0$ & & $60.4 \pm 6.0$ & & $63.2 \pm 1.8$ & \\
\hline \multirow{2}{*}{ Protein } & part & $11.7 \pm 1.2$ & \multirow{2}{*}{0.1} & $13.3 \pm 0.9$ & \multirow[t]{2}{*}{0.06} & $14.5 \pm 1.4$ & \multirow{2}{*}{0.13} & $13.5 \pm 1.6$ & 0.94 & $13.2 \pm 0.1$ & \multirow{2}{*}{0.23} \\
\hline & morv & $13.1 \pm 1.7$ & & $14.4 \pm 3.0$ & & $14.0 \pm 1.5$ & & $13.3 \pm 1.4$ & & $14.2 \pm 1.9$ & \\
\hline \multirow{2}{*}{ Fat } & part & $17.9 \pm 5.6$ & \multirow{2}{*}{0.88} & $13.6 \pm 3.5$ & \multirow{2}{*}{0.81} & $12.3 \pm 4.8$ & \multirow{2}{*}{0.25} & $12.3 \pm 4.6$ & 0.31 & $4.8 \pm 1.1$ & \multirow{2}{*}{0.002} \\
\hline & morv & $17.5 \pm 4.42$ & & $14.0 \pm 1.4$ & & $14.3 \pm 3.7$ & & $14.1 \pm 1.1$ & & $13.8 \pm 1.9$ & \\
\hline \multirow{2}{*}{ Ash } & part & $1.5 \pm 0.56$ & \multirow{2}{*}{$<0.001$} & $1.3 \pm 0.4$ & \multirow{2}{*}{$<0.001$} & $2.0 \pm 0.5$ & \multirow{2}{*}{0.04} & $0.5 \pm 0.4$ & $<0.001$ & $1.4 \pm 0.2$ & \multirow{2}{*}{0.002} \\
\hline & morv & $2.6 \pm 0.82$ & & $2.3 \pm 0.3$ & & $2.3 \pm 0.3$ & & $2.6 \pm 0.4$ & & $2.3 \pm 0.7$ & \\
\hline \multirow{2}{*}{ Starch } & part & $7.1 \pm 2.6$ & \multirow{2}{*}{0.17} & $4.5 \pm 0.7$ & \multirow{2}{*}{0.23} & $4.5 \pm 1.9$ & \multirow{2}{*}{0.059} & $6.2 \pm 2.1$ & & $4.5 \pm 0.3$ & \multirow{2}{*}{0.004} \\
\hline & morv & $6.2 \pm 1.3$ & & $4.8 \pm 1.1$ & & $5.3 \pm 1.5$ & & - & & $5.5 \pm 0.7$ & \\
\hline & part & $5.9 \pm 0.31$ & & - & & $5.9 \pm 0.3$ & 0.52 & - & & - & \\
\hline pH & morv & $6.0 \pm 0.29$ & 0.64 & - & & $6.0 \pm 0.1$ & & - & & $6.0 \pm 0.2$ & \\
\hline Galt & part & $1.2 \pm 0.47$ & $<\cap \cap 01$ & - & & $1.2 \pm 0.3$ & - ก००1 & - & & - & \\
\hline Salt & morv & $1.0 \pm 0.0$ & $<0.001$ & - & & $1.0 \pm 0.0$ & $<0.001$ & - & & - & \\
\hline & part & $.48 \pm .23$ & 03 & - & & $0.6 \pm 0.1$ & $<0.001$ & - & & - & \\
\hline & morv & $.40 \pm 0.00$ & .03 & - & & $0.4 \pm 0.00$ & & - & & - & \\
\hline Nitrits & part & $51.0 \pm 59.4$ & & - & & $19.2 \pm 16.1$ & $<0.001$ & - & & - & \\
\hline Nitrite & morv & $74.9 \pm 0.9$ & 0.06 & - & & $73.5 \pm 5.5$ & & - & & - & \\
\hline
\end{tabular}

microbial agents available in meat products may be affected by pre-slaughter, slaughter, and meat production conditions ${ }^{[29]}$. Bacteria cause defects such as decay, discoloration, gas production, and softening during the meat products spoilage process. Moisture content is another considerable factor to assess the meat product quality ${ }^{[24]}$. High moisture content in products lead to water replacement with essential nutrients, which could reduce their shelf life. Notably, high amounts of lipids in products could increase the risks of high fat intake and cardiovascular diseases ${ }^{[30]}$. Besides, the levels of fat and moisture in a product have an inverse relationship. Another chemical effector is starch that leads to extra energy intake and could indicate the presence of high animal resources ${ }^{[31]}$. High levels of ash could also be linked to excessive use of salt such as sodium chloride, which is a major public health concern, especially for cardiovascular patients. Due to the growing population and the complex structures of today's societies, especially in large cities, the access to fresh food and vegetables has declined; thus, the tendency for fast-food to provide daily energy is growing rapidly [32]. These products contain preservatives such as nitrate and sodium nitrite to prevent the growth of microorganisms. Excessive use of these substances could endange human health because of their carcinogenic effects [33]. Consumption of processed meat products is increasing in developing countries such as Iran. In Iran, more than 50 types of heated meat products are being produced [34]. In 2005, Kamkar examined the chemical properties of sausages produced in Iran and showed that in sausages with $40-50 \%$ meat content, about 38.9 and 50 of the samples had moisture and carbohydrate contents higher than the national standard, respectively. In addition, in sausages with 51-60\% meat content, $38.2,14.7,61.8$, and $100 \%$ of the samples had moisture, fat, carbohydrate, and ash contents higher than the standard 
limits, respectively [35]. In another study by Shekarforoush et al. (2012), meat and its products were contaminated with $L$. monocytogenes. Salmonella infection was less frequent, and staphylococcal infections were more common in Kebab and during hot seasons ${ }^{[36]}$. Also, in a study carried out on the chemical and microbiological properties of meat products in Kermanshah, Iran, the contamination of the samples was as follows: $100 \%$ mold and yeast, 58\% Coliform, 53\% staphylococci, $17 \%$ E. coli, and 3\% Salmonella [37]. Sulieman et al. (2012) examining the physical and chemical properties of Agashi meat revealed the moisture $(32.76 \%$ to $72.3 \%)$, ash $(8.55 \%$ to $97 \%)$, protein $(10.5 \%$ to $30.7 \%)$, fiber $(0.2 \%$ to $81 \%)$, fat $(3.34 \%$ to $11.9 \%$ ), and carbohydrate (39\% to $45.93 \%$ ) contents of this meat. Also, the concentration of potassium, sodium, and iron in cooked meat was higher than in raw meat, ranging from 95 to $215,30.6$ to 90 , and 1.0 to 1.5 mg /100 g, respectively. High levels of yeast and mildew, Coliform, and S. aureus were identified ${ }^{[38]}$. Besides, Menendez et al. (2018) conducted a study on the physicochemical and microbiological properties of fermented meat products in Spain. Mean pH was 5.79 to 5.83, and all mean values for $\mathrm{a}_{\mathrm{w}}$ were below 0.90 . Mean count of aerobic mesophilic bacteria was more than $108 \mathrm{cfu} / \mathrm{g}$, and more than 2.3 of the samples were Enterobacteriaceae negative, while $S$. aureus was prevalent; also, Salmonella and Listeria were detected in four and five samples, respectively, $C$. botulinum was negative in the samples ${ }^{[39]}$.

\section{Conclusion}

In general, based on the results of the present and other studies in different countries, it could be concluded that a significant number of samples have chemical and microbial levels higher than the specified national standards. The present study results showed that the standards set for the chemical and microbial quality of meat products in Iran are partially enforced by factories, but it should be noted that meat products form a significant part of today's food chain. The results in some cases are contradictory to national standards, which could cause health problems and reduce the intake of essential nutrients through such products. Given the discrepancies between the obtained results and the national standard limits, it is likely that surveillance and control measures are taken less than that expected; thus, it is recommended that the production process of these products be monitored more closely.

\section{Acknowledgment}

The data analyzed in this study were from a laboratory of the Food and Drug Administration in Hamadan and a meat processing company. We would like to thank the management of the laboratory as well as the manufacturing company, ultimately contributing to this study.

Ethical Permission: We certify that all data collected during the study are presented in this manuscript, and no data from the study have been or will be published separately.

Conflict of interest: The authors declare no conflict of interest.

Authors Contribution: Conceptualization: MA; Data curation: SM ; Formal analysis: SM; Funding acquisition: no funding; Investigation: MA, MP; Methodology: MA, MA, MP ; project administration:

EMA; Resources: MA; Software: SM; Supervision: EMA; Writing of the original draft: MA, MA; Writing-review and editing: MA.

Fundings: There was no funding.

Consent to participate: Not applicable.

\section{References}

1. Nemati Niko Z, Jahed Khaniki G, Alikord M, MolaeeAghaee E. ELISA and copan based evaluation and analysis of antibiotic residues in cattle milk in Qazvin, Iran. Infect Epidemiol 
Microbiol. 2020;6(3):219-27.

2. Uradziński J, Weiner M. Food additives used in meat processing according to the Polish and European Union legislation. Pol J Vet Sci. 2003;6(2):173-6.

3. World Health Organization. The state of food security and nutrition in the world 2018: Building climate resilience for food security and nutrition: Food \& Agriculture Organization; 2018.

4. Alikord M, Momtaz H, keramat J, Kadivar M, Rad AH. Species identification and animal authentication in meat products: A review. J Food Meas Charact. 2018;12(1):145-55.

5. Alikord M, Keramat J, Kadivar M, Momtaz H, Eshtiaghi MN, Homayouni-Rad A. Multiplex-PCR as a rapid and sensitive method for identification of meat species in halal-meat products. Recent Pat Food Nutr Agric. 2017;8(3):175-82.

6. Alikord M, Mohammadi A, Kamankesh M, Shariatifar N. Food safety and quality assessment: comprehensive review and recent trends in the applications of ion mobility spectrometry (IMS). Crit Rev Food Sci Nutr. 2021:1-34.

7. Bolinius DJ, Sobek A, Löf MF, Undeman E. Evaluating the consumption of chemical products and articles as proxies for diffuse emissions to the environment. Environ Sci Process Impacts. 2018;20(10):1427-40.

8. Amit SK, Uddin MM, Rahman R, Islam SR, Khan MS. A review on mechanisms and commercial aspects of food preservation and processing. Agric Food Secur. 2017;6(1):1-22.

9. Rehman NU, Hussain J, Ali L, Khan AL, Mabood F, Gillani SA, et al. Nutritional assessment and mineral composition of some selected edible vegetables. Eur J Med Plants. 2014;4(4):444-57.

10. Zerabruk K, Retta N, Muleta D, Tefera AT. Assessment of microbiological safety and quality of minced meat and meat contact surfaces in selected butcher shops of Addis Ababa, Ethiopia. J Food Qual. 2019;2019.

11. Miraglia D, Ranucci D, Trabalza-Marinucci M, Acuti G, Forte C, Codini M, et al. Microbiological, chemical-physical, and sensory characteristics of Fabriano salami from pigs fed Oregano vulgaris extract. Ital J Food saf. 2017;6(4):6906.

12. Bintsis T. Microbial pollution and food safety. AIMS Microbiol. 2018;4(3):377-96.

13. Bhunia AK. Foodborne microbial pathogens: Mechanisms and pathogenesis. Springer; 2018.

14. Barbieri F, Montanari C, Gardini F, Tabanelli G. Biogenic amine production by lactic acid bacteria: A review. Foods. 2019;8(1):17.

15. Dehkordi MK, Shamsabadi MG, Banimehdi P. The occurrence of Staphylococcus aureus, enterotoxigenic and methicillin-resistant strains in Iranian food resources: A systematic review and meta-analysis. Ann Ig. 2019;31(3):263-78.

16. Association of Official Analytical Chemists. Official methods of analysis. $15^{\text {th }}$ ed. USA, TX: Association of Official Analytical Chemists, Arlington; 1990, Vol. 97331.

17. Regulation EC. No. $1151 / 2012$ of the European Parliament and of the council of 21 November 2012 on quality schemes for agricultural products and foodstuffs. OJ L343/1. 14.12.2012.

18. Giatrakou V, Ntzimani A, Savvaidis I. Effect of chitosan and thyme oil on a ready to cook chicken product. Food Microbiol. 2010;27(1):132-6.

19. Siripatrawan U, Noipha S. Active film from chitosan incorporating green tea extract for shelf life extension of pork sausages. Food Hydrocoll. 2012;27(1):102-8.

20. Petrou S, Tsiraki M, Giatrakou V, Savvaidis I. Chitosan dipping or oregano oil treatments, singly or combined on modified atmosphere packaged chicken breast meat. Int J Food Microbiol. 2012;156(3):264-71.

21. Vasilatos G, Savvaidis I. Chitosan or rosemary oil treatments, singly or combined to increase turkey meat shelf-life. Int J Food Microbiol. 2013;166(1):54-8.

22. Association of Official Analytical Chemists. AOAC official method 976.30-1979, Clostridium perfringens in foods. Microbiologi. Association of Official Analytical Chemists; 1979.

23. Association of Official Analytical Chemists. Official methods of analysis. $15^{\text {th }}$ ed. Washington, DC: Association of Official Analytical Chemists; 1991.

24. Borch E, Kant-Muermans M-L, Blixt Y. Bacterial spoilage of meat and cured meat products. Int J Food Microbiol. 1996;33(1):103-20.

25. Kotsanopoulos KV, Arvanitoyannis IS. The role of auditing, food safety, and food quality standards in the food industry: A review. Compr Rev Food Sci Food Saf. 2017;16(5):760-75.

26. Syne S-M, Ramsubhag A, Adesiyun AA. Microbiological hazard analysis of ready-to-eat meats processed at a food plant in Trinidad, West Indies. Infec Ecol Epidemiol. 2013;3(1):20450.

27. Camino Feltes MM, Arisseto-Bragotto AP, Block JM. Food quality, food-borne diseases, and food safety in the Brazilian food industry. Food Qual Saf. 2017;1(1):13-27.

28. Kadariya J, Smith TC, Thapaliya D. Staphylococcus aureus and staphylococcal food-borne disease: an ongoing challenge in public health. BioMed Res Int. 2014;2014.

29. Rani Z, Hugo A, Hugo C, Vimiso P, Muchenje V. Effect of post-slaughter handling during distribution on microbiological quality and safety of meat in the formal and informal sectors of South Africa: A review. S Afr J Anim Sci. 
2017;47(3):255-67.

30. Baek KH, Utama DT, Lee SG, An BK, Lee SK. Effects of replacing pork back fat with canola and flaxseed oils on physicochemical properties of emulsion sausages from spent layer meat. Asian-Australas J Anim Sci. 2016;29(6):865-71.

31. Mann J, Truswell AS. Essentials of human nutrition. Oxford University Press; 2017.

32. Kong YW, Baqar S, Jerums G, Ekinci EI. Sodium and its role in cardiovascular disease-the debate continues. Front Endocrinol. 2016;7:164.

33. Parvizishad M, Dalvand A, Mahvi AH, Goodarzi F. A review of adverse effects and benefits of nitrate and nitrite in drinking water and food on human health. Health Scope. 2017;6(3):e14164.

34. Jalali M, Abedi D. Prevalence of Listeria species in food products in Isfahan, Iran. Int J Food Microbiol. 2008;122(3):336-40.

35. Kamkar A. Determination of hydroxyproline as measure of collagen content in meat product by colorimetric method. J Vet Res. 2005;60(1):25-30.

36. Shekarforoush S, Rokni N, Karim G, Razavi RS, Kiaie S, Abbasvali M. Study on the overview on food borne bacteria in foodstuffs with animal origin in Iran, part two. Meat and meat products. Food Hyg. 2012;2(3 (7)):1-14.

37. Sadeghi E, Hashemian A, Mohammadi M, Mohammadi R. Study on the microbiological and chemical characterization of the meat products consumed in Kermanshah in 2012. Iran J Nutr Sci Food Technol. 2013;7(5):281-6.

38. Sulieman AM, Abdelhai M, Babiker ER. Some chemical and microbiological characteristics of Agashi meat product. 2012;3(6):1-6.

39. Menéndez RA, Rendueles E, Sanz JJ, Santos JA, García-Fernández MC. Physicochemical and microbiological characteristics of diverse Spanish cured meat products. CyTA J Food. 2018;16(1):199-204. 